\title{
Modelowanie kompetencji opiekunów seniorów w pracy projektowej i coachingu indywidualnym - projekt EduCare
}

Developing competences and skills of senior care assistants through project-based learning and individual coaching the EduCare project

Streszczenie. Tekst opisuje podstawowe założenia projektu EduCare, którego celem jest stworzenie modelu kształcenia nowoczesnego opiekuna osoby starszej. Autorki przedstawiają model szkolenia przeprowadzonego z wykorzystaniem nowoczesnych metod, takich jak coaching, metoda projektowa i e-learning.

Słowa kluczowe: projekt EduCare, opiekun osoby starszej, coaching, kształcenie opiekunów.

Summary. The text describes the main objectives of the EduCare project which aims at creating a new model of senior care assistants' education. The authors present the model of training conducted with the application of modern teaching methods, such as coaching, project-based learning and e-learning.

Key words: EduCare project, senior care assistants, coaching, carer education.

\section{Profesjonalizm współczesnego opiekuna seniorów}

Starzenie się społeczeństw całej Europy ujawnia silną potrzebę kształcenia wykwalifikowanych kadr, mających profesjonalne przygotowanie do pracy z seniorami. Ich celem jest podniesienie jakości życia osób starszych poprzez działania opiekuńcze, pomocowe oraz promowanie zdrowej, aktywnej starości. Raport Komisji Europejskiej (2008) dotyczący opieki społecznej podkreśla niską jakość działań pomocowych i konieczność ich usprawnienia. 
W wielu krajach członkowskich UE podejmowane są inicjatywy zmierzające do zmniejszenia pomocy instytucjonalnej i rozbudowania systemu opieki domowej, odpowiadającej na potrzeby ludzi w podeszłym wieku (tzw. tailor-made). Według analiz OECD (Jacobzone, 1999) większość krajów odczuwa konieczność budowania i rozwijania modelu pomocy domowej lub organizowanej przez społeczności lokalne oraz zapewnienia jego wysokiego poziomu. Wskazuje się również na konieczność uznania kompetencji osób zajmujących się seniorami w ramach opieki rodzinnej, nabytych w praktyce, oraz możliwość rozwijania ich umiejętności interpersonalnych (np. radzenie sobie ze stresem, umiejętności organizacyjne i negocjacyjne, empatia) i opiekuńczych (np. podawanie leków). Jako przykłady wspomnianych działań wybrano projekty i inicjatywy w krajach, które są partnerami w projekcie EduCare (poza Polską to Włochy, Rumunia i Hiszpania).

Jednym z takich przedsięwzięć jest projekt Life After Care, w którym udział wzięły organizacje z Grecji, Irlandii, Wielkiej Brytanii i Włoch. Kolejny projekt - GERAS - miał na celu kształcenie opiekunów osób starszych poprzez wymianę doświadczeń, badania i współpracę międzydyscyplinarną profesjonalistów zajmujących się opieką nad seniorami (GERAS, s. 10, 31). Ciekawą inicjatywą był międzynarodowy projekt Lalera TOI (Language Learning by Radio Transfer of Innovation) realizowany w ramach programu Leonardo Da Vinci przez Włochy, Rumunię i Hiszpanię, którego celem było nauczanie języka przez radio i rozwój umiejętności zawodowych. Grupą docelową byli cudzoziemcy (Rumuni) pracujący jako opiekunowie osób starszych we Włoszech lub planujący podjęcie takiej pracy. Kolejnym przykładem jest Projekt EduSenior zrealizowany w Hiszpanii i Finlandii, który miał na celu doskonalenie pracowników, specjalistów i nauczycieli pracujących w instytucjach edukacyjnych dla seniorów poprzez łączenie doświadczeń praktycznych z wiedzą teoretyczną oraz nabywanie umiejętności w korzystaniu z dostępnych narzędzi wspomagania edukacji osób starszych, w tym ICT.

W Polsce kształcenie opiekunów osób starszych odbywa się głównie w szkołach pomaturalnych i na uniwersytetach; pojawia się także szeroka oferta szkoleniowa, która jest ukierunkowana na rozwijanie i doskonalenie kompetencji zawodowych oraz podniesienie wiedzy w zakresie metodyki uczenia osób starszych (projekt „Metody edukacji osób starszych” prowadzony przez Stowarzyszenie Trenerów Organizacji Pozarządowych) lub dzielenie się dobrymi praktykami z zakresu edukacji seniorów (projekt Centrum Inicjatyw Senioralnych o nazwie AWAKE, obejmujący Włochy, Litwę, Hiszpanię, Łotwę, Rumunię i Polskę). 
Wiele innych przedsięwzięć europejskich zmierza zatem w kierunku profesjonalnego kształcenia opiekunów seniorów, rozwijania ich kwalifikacji (również w formie kursów przez Internet, np. Universal Class) lub nawet ich certyfikowania (np. grecki projekt Elderly Care Vocational Skill Building and Certification - ECVC). Jedną $\mathrm{z}$ takich inicjatyw jest międzynarodowy projekt EduCare realizowany w ramach programu Grundtvig.

\section{Projekt EduCare}

Projekt EduCare (Education for Care $)^{1}$ jest projektem międzynarodowym, w którym partnerami są Uniwersytet Tuscia w Viterbo (Włochy), organizacja pozarządowa Entropy Knowledge Network z Viterbo (Włochy), Uniwersytet Babes Bolyai (Rumunia), Uniwersytet Jaume (Hiszpania) oraz Uniwersytet Jana Kochanowskiego w Kielcach. Jego głównym celem jest stworzenie sylwetki „nowoczesnego opiekuna współczesnego seniora” oraz opracowanie i pilotaż modelu jego szkolenia. Projekt zakłada zastosowanie nowoczesnych metod szkoleniowych, takich jak coaching, metoda projektowa i e-learning. Innowacyjny charakter EduCare polega również na silnym uwypukleniu relacji opiekun-senior oraz rozwijaniu komunikacji i zrozumienia między nimi.

W ramach pierwszego etapu projektu EduCare, we wszystkich krajach partnerskich, dokonano diagnozy potrzeb osób starszych i ich asystentów oraz sposobu rozumienia relacji opiekun-senior. Przeprowadzono badania fokusowe w trzech grupach beneficjentów projektu: osób starszych (56 respondentów), ich opiekunów (43) i ich tzw. „trenerów” tych opiekunów (33), którymi byli pracownicy uniwersytetów kształcących przyszłych asystentów osób starszych, psychologowie lub pracownicy socjalni z doświadczeniem w pracy z seniorami. Badania miały charakter jakościowy i stanowiły podstawę do określenia sylwetki współczesnego opiekuna seniora. W oparciu o wyniki badań fokusowych stworzono program szkolenia (5 działów, 36 h) oraz opis jego efektów - nabytej wiedzy, kompetencji społecznych i rozwiniętych umiejętności. W celu przedstawienia sposobu ich opisu i charakteru poniżej przedstawione są przykładowe efekty kształcenia² ${ }^{2}$.

1 Projekt nr 527360-LLP-1-2012-1-IT-GRUNDTVIG-GMP (umowa nr 2012-3762/001-001) finansowany przez Unię Europejską w ramach Programu Uczyć się przez całe życie, akcja Grundtvig, okres realizacji: XI 2012-X 2014.

2 Dokładny opis programu szkolenia i wszystkie efekty zostaną opisane w książce New Caregiver for New Elderly People pod red. G. Biggio, Cluj-Napoca 2015, Risoprint. 
1. Podstawy antropologii i gerontologii $(6 \mathrm{~h})$ : opiekun po zakończonym szkoleniu (W -wiedza) zna podstawową terminologię gerontologiczną, definiuje teorie rozwoju człowieka, objaśnia funkcjonowanie struktur i instytucji społecznych; (U - umiejętności) interpretuje zjawiska społeczne i zachowania osób starszych, diagnozuje ich potrzeby i na nie adekwatnie odpowiada, wykorzystuje wiedzę z gerontologii i analizuje problemy międzyludzkie; (K kompetencje społeczne) zajmuje postawę aktywną wobec ważnych kwestii społecznych i odznacza się odpowiedzialnością w działaniu.

2. Podstawy psychologii (6 h): (W) posiada wiedzę o zdrowiu psychicznym i fizycznym, oraz o społecznym i emocjonalnym funkcjonowaniu człowieka z perspektywy psychologii pozytywnej, rozumie główne problemy emocjonalne i patologie związane z wiekiem, uczy się akceptować starość; (U) wspomaga dobrobyt seniorów i ich pozytywne emocje, rozwija umiejętności akceptacji zmiany, reagowania na potrzeby seniorów, obserwowania ich oraz stosuje metody rehabilitacji; (K) rozwija postawę akceptacji potrzeb seniorów, uczy się poprzez obserwacje i refleksję.

3. Relacje pomocowe (9h): (W) zna koncepcję cyklu życia w aspekcie zaspokajania potrzeb seniorów, podstawy procesu komunikacji i techniki budowania relacji z osobą starszą; (U) rozpoznaje poziomy autonomii seniora, obserwuje jego zachowania i interpretuje je, potrafi wspomagać organizację życia osoby starszej w zgodzie z jej indywidualnością, rozumie charakter relacji pomocowych i interpersonalnych, interpretuje dynamikę zmian tych zależności; (K) posiada aktywną i otwartą postawę w stosunku do osób starszych, ma kompetencje komunikacyjne i zachowuje się empatycznie.

4. Coaching (9 h): (W) zna zasady, metody i narzędzia coachingu; (U) rozumie metodę coachingu i stosuje ją w pracy z seniorami, ustala cele i je realizuje, buduje relacje zaufania i wsparcia; (K) jest kompetentnym coachem w relacjach z seniorami/opiekunami;

5. Obsługa platformy (6 h): (W) zna obsługę platformy EduCare; (U) umie wysyłać wiadomości, używa repozytorium, forum, wiki, itd.; (K) potrafi wspierać opiekunów/seniorów w użyciu platformy w trybie narodowym i międzynarodowym.

W ramach każdego działu określono metody i techniki kształcenia; przygotowano również scenariusze szkoleń oraz materiały dydaktyczne $\mathrm{w}$ formie tradycyjnej i e-learningowej. Szkolenie zostało zaplanowane na 36 godzin lekcyjnych, a jego kontynuację stanowiła praca metodą projektów i coaching. 


\section{Innowacyjny model kształcenia opiekunów osób starszych w projekcie EduCare}

Osoby biorące udział w projekcie zostały podzielone na cztery grupy: grupę coachów (4 osoby, zespół projektowy EduCare), trenerów (15 osób, pracownicy akademiccy i opiekunowie ludzi starszych z dużym doświadczeniem), opiekunów (15 osób, czynni opiekunowie seniorów i studenci pracy socjalnej) i osób starszych (15 osób, w wieku 60+).

Innowacją wprowadzoną w projekcie było szkolenie „kaskadowe”, w dwóch kierunkach - „z góry na dół” i „od dołu do góry”, które przyjęło następującą formę.

1. Pierwszy etap to szkolenie dla tzw. trenerów i opiekunów przeprowadzone w oparciu o wspólnie wypracowany model przez zespoły EduCare (coachów) we wszystkich krajach z wykorzystaniem e-learningu.

2. Drugi etap to szkolenie dla opiekunów przeprowadzone przez trenerów i zespoły EduCare.

3. Członkowie zespołów EduCare stawali się coachami trenerów i dalej pracowali z nimi na pierwszym etapie w małych grupach, metodą projektową, potem indywidualnie, wykorzystując w obu formach także e-learning.

4. Coaching - każdy trener indywidualnie prowadził podopiecznego opiekuna, który zajmował się wybranym przez siebie seniorem (kontakt indywidualny, e-learning i platforma).

5. Opiekun wykonywał swoje zadania, spotykał się z seniorem i pracował nad jego rozwojem, aktywizacją lub udzielał wsparcia przy rozwiązywaniu problemów. Każde spotkanie relacjonowane było trenerowi i wraz z nim analizowane. Planowano także dalsze działania.

6. W zależności od pojawiających się trudności trenerzy pracowali samodzielnie $\mathrm{z}$ opiekunami lub wspomagali się wzajemnie w grupach projektowych.

7. Trener współpracował ze swoim coachem z zespołu EduCare i ustalał dalsze cele oraz opracowywał strategię szkolenia i wspomagania opiekuna.

Innowacją w szkoleniu opiekunów osób starszych w projekcie EduCare jest stworzenie modelu kształcenia przy wykorzystaniu kombinacji trzech metod: metody projektowej, coachingu oraz e-learningu.

Metoda projektowa została zastosowana do stworzenia sytuacji uczenia się przez doświadczenie. W tym celu trenerów podzielono na cztery grupy, uwzględniając podobieństwo miejsca pracy i ich doświadczeń w pracy z osobami starszymi. Każdy z zespołów, do której dołączał coach, formułował problemy, jakie miał rozwiązywać. W grupach projektowych ustalono 
również cele, działania, a także podjęto się określenia metod i technik pracy $\mathrm{z}$ opiekunami. Zgodnie z założeniami metody projektu trenerzy powinni systematycznie zdawać relację z postępów, konsultować je i wspólnie omawiać. Forma ta została jednak zintegrowana $\mathrm{z}$ coachingiem, stąd w zależności od sytuacji w każdej grupie projektowej schemat działania był inny. Każda grupa pracowała razem, spotykając się w miejscu pracy, wzajemnie wspomagając i konsultując, lecz każdy z trenerów miał również spotkania indywidualne $\mathrm{z}$ coachem. Konsultacje i dyskusje w grupach projektowych i w ramach coachingu pozwalały spojrzeć krytycznie na własne działania, przełamać trudności i zmodyfikować zaplanowane działania. Praca projektowa i coaching wspomagane były e-learningiem. Dzięki użyciu platformy uczestnicy mieli możliwość uzupełniania wiedzy i samokształcenia, uzyskiwali wskazówki do dalszego samodzielnego uczenia się (również w formie zadań przekazanych od coachów), a także wymieniali się informacjami i dyskutowali w ramach określonych grup projektowych oraz z innymi uczestnikami szkolenia, w Polsce i krajach partnerskich.

Celem działań coachingowych $\mathrm{w}$ projekcie było wspomaganie pracy opiekuna podczas wykonywania zadań, a w szczególności: wzmacnianie umiejętności nawiązywania i podtrzymywania relacji z seniorem, negocjowanie, radzenie sobie ze stresem, rozwijanie umiejętności motywowania seniora do aktywnego życia, rozwiązywanie problemów osobistych lub w środowisku pracy. Coaching był działaniem celowym, cyklicznym i etapowym, opartym na pięciu krokach:

1. Określenie celów i pożądanych rezultatów opieki - omówienie sytuacji, określenie jej charakteru (instytucjonalna, rodzinna, indywidualna), treści i stanu psychofizycznego seniora.

2. Poszukiwanie możliwości i potencjału - diagnoza sytuacji osoby starszej i uwarunkowań osobowych i środowiskowych.

3. Wdrażanie planu działania - praca indywidualna z seniorem/opiekunem, dostosowywanie działania asystenta, doraźne reagowanie na pojawiające się trudności, poszukiwanie nowych rozwiązań.

4. Usuwanie przeszkód w realizacji - omówienie przebiegu opieki, analiza zachowań seniora i jego stanów emocjonalnych, określenie charakteru relacji (progresywny lub regresywny - a wtedy poszukiwanie przyczyn regresji), a także analiza sposobów komunikowania się (np. powtarzanie i wskazywanie na cele, uzasadnianie podejmowanych działań, tłumaczenie przebiegu kolejnych kroków i motywów działania, odroczona ocena, zachęcanie do działania, wtórne motywowanie itd.). 
5. Podsumowanie rezultatów i planowanie kolejnych etapów - próba określenia poziomu komunikacji i wypracowanych więzi (lub ich braku), określenie możliwości dalszej współpracy przy wykorzystaniu zaistniałych strategii i metod, wskazanie na nowe obszary rodzinnego/technologicznego/społecznego funkcjonowania seniora.

\section{Ewaluacja modelu EduCare}

Ewaluacja założeń projektu i ocena efektywności szkolenia opiekunów została wykonana przy wykorzystaniu różnorodnych metod i technik badawczych:

1. Test wiedzy oceniający wiedzę trenerów opiekunów w skali punktowej 0-10, stanowiący podstawę ich kwalifikacji do rozpoczęcia szkoleń opiekunów, pracy projektowej i coachingu. Średnia uzyskana przez trenerów to 9,2 oznaczająca bardzo wysoki poziom nabywania wiedzy.

2. Arkusz obserwacyjny zawierający stwierdzenia opisujące zachowania, odnoszące się do założonych efektów kształcenia, z podziałem na wiedzę, umiejętności i kompetencje społeczne. Zostały one wypełnione (1) przez coachów (zespół EduCare) w kontekście pracy trenerów z opiekunem oraz (2) przez trenerów, którzy oceniali kompetencje swoich opiekunów podczas ich pracy z seniorami w skali od 0 (nigdy) do 4 (bardzo często). U wszystkich opiekunów i ich trenerów zaobserwowano znaczne podwyższenie poziomu wiedzy (o 22,5\% u trenerów i 35\% opiekunów), co jest zrozumiałe, bowiem tematyka szkolenia w większości przypadków nie była dobrze znana uprzednio. Zjawisko to dotyczy najsilniej dwóch zakresów tematycznych - wykorzystania coachingu (największa zmiana) i platformy e-learningowej. Najmniejszy przyrost kompetencji trenerów i opiekunów zaobserwowano przy ocenie kompetencji społecznych (o 7,5\% w obu grupach). Duże różnice natomiast zaobserwowano pomiędzy rozwojem umiejętności trenerów (o 11,5\%) i ich opiekunów (27,5\%), co jest zrozumiałe, bowiem trenerzy to osoby z dużym doświadczeniem i przyrost ich umiejętności jest znacznie trudniejszy niż w przypadku opiekunów, wchodzących w rolę zawodową lub na początku swojej pracy. Wynik taki potwierdza również konieczność zdobywania umiejętności poprzez praktykę, która umożliwiło zastosowanie metody projektów i coachingu.

3. Kwestionariusz samooceny kompetencji dla trenerów i opiekunów, którego wyniki potwierdziły wyniki obserwacji i dookreśliły ich charakter w zakresie treści (poznanie coachingu i obsługi platformy) oraz siły 
(np. 15-100\% opiekunów uważa, że ich umiejętności nawiązywania relacji z seniorem są bardzo dobre, 12-80\% odczuwa pewność, że okazuje empatię seniorom, 10-67\% osób wysoko ocenia swoją otwartość na potrzeby ludzi starych).

4. Badania fokusowe zorganizowane w formie panelu dyskusyjnego z trenerami, opiekunami i seniorami. Wypowiedzi uczestników pozwoliły na zebranie wielu przykładów rozwoju umiejętności i kompetencji - pozytywnych zmian w relacjach między seniorem i opiekunem oraz opiekunem i trenerem.

Jak wskazały analizy i badania, za istotną wartość zaproponowanej w projekcie EduCare formy szkolenia należy uznać stworzenie pozycji trenera, postrzeganego jako mentora, doradcę, osobę z jednej strony kontrolującą budowanie relacji, ale i zapewniającą dodatkowe wsparcie oraz pobudzającą opiekuna do pracy nad sobą poprzez wypracowanie wspólnych metod rozwiązywania pojawiających się trudności. Dzięki systematycznym relacjom z trenerem opiekun może szybciej reagować na potrzeby seniora, a jego rady nadają pracy właściwy kierunek. Minusem takiej relacji może być jednak mniejsza gotowość do usamodzielnienia się opiekuna w podejmowanych działaniach. W wielu wypadkach między seniorem i asystentem z czasem wywiązywała się także więź emocjonalna, relacja osobista. Zmieniło się postrzeganie osób starszych, a wiek nie był barierą.

We współczesnym świecie opiekun staje się bardziej asystentem, doradcą, przyjacielem i towarzyszem seniora. Dynamiczne zmiany społeczne i demograficzne powodują zmianę pojmowania jego roli, narzucają konieczność stałego poszerzania wiedzy i nabywania nowych umiejętności. Stąd i formuła szkolenia lub kształcenia opiekunów/asystentów musi uwzględniać nowe formy i metody. Zastosowane metody szkolenia opiekunów w projekcie EduCare przyniosły zakładane rezultaty. Szeroko zakrojone badania, obserwacje, analizy i treningi stanowią adekwatną odpowiedź na potrzeby współczesnych opiekunów i ich podopiecznych. Dzięki szkoleniu EduGare uczestnicy zdobyli dużą wiedzę i umiejętności, przede wszystkim w zakresie komunikacji, ale też o charakterze poznawczym, pomocowym i niekiedy medycznym. 


\section{Bibliografia}

De Vincenti C. (2000), Gli anziani in Europa. Sistemi sociali e modelli di welfare a confronto (IX Rapporto Cer-Spi), tłum. na ang. G. Biggio, Laterza, Roma-Bari.

Giamakouris K. (2008), Population and social conditions, tłum. A.Szplit, "Eurostat. Statistics in focus. 72/2008".

Głowacka M., Jarosz M. J., Włoszczak-Szubzda A., Dzierżek J. (2011), Zmiany demograficzne w Polsce, [w:] Jarosz M. J., Włoszczak-Szubzdy A., Kowalski W. (red.), Problemy starzenia się społeczeństwa. Teoria i praktyka. Perspektywa polska i brytyjska, Innovatio Press, Lublin, s. 87-88.

Jacobzone S. (1999), Ageing and Care for Frail Elderly Persons: An Overview of International Perspectives, tłum. A. Szplit, OECD Labour Market and Social Policy Occasional Paper, no. 38.

Oliva J., Vilaplana C., Osuna R. (2011), The social value of informal care provided to elderly dependent people in Spain, tłum. na ang. S. Quero, "Gaceta Sanitaria”, vol. 2 (25), s. 108-114.

Rogero-García, J. (2009), Distribución en España del cuidado formal e informal a las personas de 65 años y más años en situación de dependencia, tłum. na ang. S. Quero, "Revista Española de Salud Pública”, vol. 83, Redalyc, s. 393-405.

Szukalski P. (2004), Osoby sędziwe w Polsce i w krajach Unii Europejskiej. Przeszłość, teraźniejszość, przyszłość, „Prace Instytutu Ekonometrii i Statystyki Uniwersytetu Łódzkiego", seria A, s. 6-9.

Tobío C., Agulló M. S., Gómez M. V., Martín-Palomo M. T. (2010), El cuidado de las personas. Un reto para el siglo XXI, tłum. na ang. S. Quero, Fundación La Caixa, Barcelona.

\section{Netografia}

EduSenior, http://www.edusenior.eu/data/outcomes/wp5/EduSenior-guide.pdf (dostęp: 02.03.2014).

Elderly Care Vocational Skill Building and Certification, http://interlinks.euro. centre.org/model/example/ElderlyCareVocationalSkillBuildingAndCertification_ECVC (dostęp: 12.07.2014).

GERAS Strategic plan 2013-2018, Geriatric Education and Research in Aging Science Centre, http://www.hamiltonhealthsciences.ca/workfiles/PR/ SPH\%20GERAS\%20Report.pdf (dostęp: 12.07.2014).

Life After Care, http://www.lifeaftercare.eu/pd.php (dostęp: 12.07.2014).

Projekt AWAKE, http://centrumis.pl/projekt-awake.html (dostęp: 12.07.2014).

Projekt „Metody edukacji osób starszych”, http://www.kampania60plus.pl/aktualnosci/projekt-metody-edukacji-osob-starszych.html (dostęp: 10.01.2015). 


\section{6 | Agnieszka Szplit, Małgorzata Stawiak-Ososińska}

Raport Komisji Europejskiej pt. Long-term Care in the European Union, (2008), http:// ec.europa.eu/social/BlobServlet?docId=768\&langId=en (dostęp: 2012-2014).

Rocznik statystyczny Rzeczypospolitej Polskiej (2013), Warszawa, http://www. stat.gov.pl/cps/rde/xbcr/gus/RS_rocznik_statystyczny_rp_2013.pdf (dostęp: 20.08.2014).

Universal Class: Social Work Online Courses, http://www.universalclass.com (dostęp: 12.07.2014). 